\title{
PHGDH Gene
}

National Cancer Institute

\section{Source}

National Cancer Institute. PHGDH Gene. NCI Thesaurus. Code C99474.

This gene plays a role in amino acid synthesis. 